\title{
Global Trends in Transnational Education
}

\author{
Betsy J. Bannier, Senior Member, IACSIT
}

\begin{abstract}
The realities of globalization, both positive and negative, dominate the landscape of higher education. Transnational education programs allow students to pursue higher education in other countries without physically relocating. These programs offer collaborative learning opportunities which are valuable for increasingly globalized societies, and hold great potential for developing countries. However, concerns regarding cultural compromise and quality assurance remain. This article highlights current global trends in transnational education, with a dual focus on culture and quality.
\end{abstract}

Index Terms-Transnational education, online education, distance education, globalization.

\section{INTRODUCTION}

Transnational education is an umbrella term encompassing many of the educational platforms more commonly labeled as distance education, online education, collaborative education, for-profit education, and satellite campus teaching. While transnational education is inherently international in scope, different terminology is used to clarify that transnational education does not require international travel.

In 2002, the Code of Good Practice in the Provision of Transnational Education ratified by the Lisbon Convention defined transnational education as "all types of higher education study Programmes, or sets of courses of study, or education services in which the learners are located in a country different from the one where the awarding institution is based. Such Programmes may belong to the educational system of a state different from the state in which it operates, or may operate independently of any national system" [1]. While this definition represents the aggregate perspective of the 47 Member States of the Council of Europe, transnational education is a global phenomenon.

The World Trade Organization (WTO), representing 159 nations and the overwhelming majority of all international trade, has taken significant interest in transnational education programs. Rules and regulations specified in the WTO's General Agreement on Trade in Services (GATS) recognize transnational education as an internationally traded service. As such, online education programs and other distance education programs which enroll students across international borders fall under the scrutiny of GATS rules and the World Trade Organization itself.

\section{INTRANATIONAL BEGINNINGS}

\section{A. Online Education}

Transnational education is the logical outgrowth of online and distance education programs, which are currently experiencing globally unprecedented growth in both scope and scale. Online education programs generate $\$ 60$ billion US Dollars (USD) per year in global revenue, accounting for an increasing percentage of total higher education revenue every year [2]. Many global regions with well-developed higher education infrastructure are experiencing a shift in momentum from traditional classrooms to the online environment, with an estimated $25 \%$ of all higher education students in India, along with 30\% in the United States and $40 \%$ in Turkey, enrolling in distance education programs [3], [4].

Regions with less well-developed higher education infrastructure are also experiencing promising growth in the online arena. For example, while the African continent has the lowest rate of higher education participation overall, online education is increasingly used as a means of circumventing physical and geographical barriers to university access [5].

As online education opportunities expand, the collective body of research grows increasingly global in scope. Table I illustrates a sampling of recent intranational online education research. While the nations and programs studied vary, an emphasis on evaluating quality and the effects of globalization appear to be common threads.

TABLE I: SINGLE NATION STUDIES

\begin{tabular}{|c|c|c|c|}
\hline Country & Emphasis & Researchers & Year \\
\hline China & $\begin{array}{l}\text { Legal, quality, and cultural } \\
\text { issues }\end{array}$ & Yang & 2008 \\
\hline China & Marketing & Altbach & 2013 \\
\hline China & $\begin{array}{l}\text { World Trade Organization } \\
\text { opportunities }\end{array}$ & $\mathrm{Xu}$, Kan & 2013 \\
\hline China & Student perceptions & Fang, Wang & 2014 \\
\hline Finland & Quality assurance & Saarinen & 2008 \\
\hline Iran & $\begin{array}{l}\text { Internationalization of } \\
\text { curriculum }\end{array}$ & Zare & 2013 \\
\hline Romania & $\begin{array}{l}\text { Participation Statistics, } \\
\text { student satisfaction }\end{array}$ & $\begin{array}{l}\text { Tutunea, Rus, } \\
\text { Toader }\end{array}$ & 2009 \\
\hline Saudi Arabia & $\begin{array}{l}\text { Cultural issues, student } \\
\text { satisfaction }\end{array}$ & Hamdan & 2014 \\
\hline $\begin{array}{l}\text { United Arab } \\
\text { Emirates }\end{array}$ & Student satisfaction & $\begin{array}{l}\text { Wilkins, } \\
\text { Balakrishnan }\end{array}$ & 2013 \\
\hline United States & Participation Statistics & Allen, Seaman & 2013 \\
\hline United States & Legal issues & $\begin{array}{l}\text { Lane, Kinser, } \\
\text { Knox }\end{array}$ & 2013 \\
\hline
\end{tabular}

Top to bottom: references [4], [6]-[15]

\section{B. Open Education}

Open education or free access programs are a close cousin
Manuscript received June 8, 2014; revised September 15, 2014.
B. Bannier is with Lake Region State College, Devils Lake, ND 58301 USA (e-mail: betsy.bannier@lrsc.edu). 
of traditional online education, as the majority of open education resources and free classes are offered in an online format. While myriad open education opportunities exist, two of the more common types are Massive Open Online Courses and open universities.

Massive Open Online Courses or MOOCs are quite popular and are indeed massive, with an average course enrollment of 43,000 students [16]. MOOC popularity appears to have already peaked, as enrollment numbers have dropped slightly each of the past few years.

Where MOOCs are arguably on the decline, open universities are gaining in popularity. The first Open University opened its virtual doors in the UK in 1971. The concept of free higher education learning opportunities was instantly popular and expanded fairly quickly, with the first Open University in India accepting students in 1982. Economies of scale have allowed the open university concept to remain easily financially solvent, even as conventional higher education institutions are increasingly facing financial restraints [17].

Today, the open university concept is expanding rapidly on the African continent. With instruction and learning materials available free of charge, learners need only web access through a computer or mobile phone to participate. Sub-Saharan Africa is experiencing the strongest growth in mobile phone subscriptions in the world [3]. This growth is a likely factor in open university expansion, particularly at African Virtual University and Sudan Open University (SOU). SOU has enrolled 93,000 students in the past decade, and now offers on online library [18].

\section{TRANSNATIONAL INITIATIVES}

From the humble beginnings of early online and open education initiatives, transnational education has emerged and continues to grow at an unprecedented rate. Table II presents a cross-section of research examining transnational education programs throughout the world. The English-speaking nations of Australia, UK, and US lead the world in the export of transnational education programs, with approximately 2,400 degrees offered in English in mainland Europe alone [19]. China, India, Malaysia, Singapore, and Hong Kong are home to the largest numbers of transnational education students, the majority of whom are enrolled in Australian, UK, or US institutions.

Global growth in transnational education has been heavily impacted by two nations, India and China. Both India and China have doubled their higher education enrollment over the past decade [3]. This startling growth is expected to continue, with Asia representing an estimated $70 \%$ of global demand for international higher education within the next ten years [19].

Along with rapid growth, these heavily populated nations are experiencing a shift in import-export dynamics in higher education. In 2007 for example, foreign students earned over two-thirds of all engineering doctoral degrees granted by universities in the United States; the majority of those students were from India and China [20]. Since that time, China has become one of the top ten host countries for higher education in the world. Approximately 1,400 foreign institutions currently offer higher education programs in China, the majority of which are Australian [6], [7].

Australian institutions host the highest concentration of foreign students, with almost one-quarter of their collective student body claiming citizenship in other countries. In comparison, less than five percent of higher education students enrolled in US institutions claim foreign citizenship [20].

In the Middle East, the United Arab Emirates (UAE), Quatar, and Bahrain function as regional centers for transnational education programs. UAE hosts the largest number of branch campuses globally, with high rates of student satisfaction [21]. The Kingdom of Saudi Arabia has been working collaboratively with Canada on transnational education efforts since 2003, with King Fahd University in Dhahran building e-learning initiatives with the University of British Columbia [13]. More recently, the Islamic Republic of Iran began exploring transnational education opportunities, including the logistics of redesigning curricula to expand English language usage, accommodate foreign students, and budget for marketing purposes [11].

\section{TABLE II: INTERNATIONAL AND MULTINATIONAL STUDIES}

\begin{tabular}{|c|c|c|c|}
\hline Countries & Emphasis & Researchers & Year \\
\hline France, India & Commodification, legal issues & $\begin{array}{l}\text { Pilkington, } \\
\text { Nair }\end{array}$ & 2013 \\
\hline Australia, India & Legal and quality issues & $\begin{array}{l}\text { Stella, } \\
\text { Woodhouse }\end{array}$ & 2011 \\
\hline Germany, US & Cultural competency & May & 2013 \\
\hline $\begin{array}{l}\text { Malaysia, } \\
\text { Australia }\end{array}$ & $\begin{array}{l}\text { Marketing, postcolonialism, } \\
\text { ethno-nationalism }\end{array}$ & $\begin{array}{l}\text { Sidhu, } \\
\text { Christie }\end{array}$ & 2014 \\
\hline Kenya, UK & $\begin{array}{l}\text { Investment, development, } \\
\text { legal issues }\end{array}$ & Aggarwal & 2013 \\
\hline Japan, Australia & Curriculum & Nichol & 2103 \\
\hline $\begin{array}{l}\text { Hong Kong, } \\
\text { Malaysia, } \\
\text { Australia }\end{array}$ & Legal and quality issues & $\begin{array}{l}\text { McBurnie, } \\
\text { Ziguras }\end{array}$ & 2001 \\
\hline $\begin{array}{l}\text { Australia, } \\
\text { Singapore, } \\
\text { Malaysia }\end{array}$ & Quality assurance & Lim, Evans & 2011 \\
\hline $\begin{array}{l}\text { US, UK, } \\
\text { Australia }\end{array}$ & Quality assurance & Smith & 2010 \\
\hline $\begin{array}{l}\text { UK, Hong } \\
\text { Kong }\end{array}$ & Social capital & $\begin{array}{l}\text { Waters, } \\
\text { Leung }\end{array}$ & 2013 \\
\hline China, Australia & $\begin{array}{l}\text { Quality, educational } \\
\text { imperialism }\end{array}$ & Pyvis & 2011 \\
\hline China, India & $\begin{array}{l}\text { National knowledge, values, } \\
\text { socialization }\end{array}$ & Kumar & 2014 \\
\hline $\begin{array}{l}\text { Sierra Leone, } \\
\text { Nigeria, Sudan, } \\
\text { India, US, }\end{array}$ & & & \\
\hline $\begin{array}{l}\text { Australia, } \\
\text { Malaysia, } \\
\text { Singapore, } \\
\text { Hong Kong }\end{array}$ & Infrastructure, technology & Deb & 2013 \\
\hline $\begin{array}{l}\text { Africa } \\
\text { (unspecified } \\
\text { countries) }\end{array}$ & Quality assurance & Barasa & 2010 \\
\hline $\begin{array}{l}\text { Southwest } \\
\text { Pacific/SE Asia } \\
\text { region ( } 24 \\
\text { countries) }\end{array}$ & Legal and cultural issues & $\begin{array}{l}\text { Tynan, } \\
\text { James }\end{array}$ & 2013 \\
\hline
\end{tabular}

Top to bottom: references [1], [5], [17], [18], [22]-[32]

In addition to broad multinational efforts, interesting niche programs have been developed to help students gain cross-cultural experience in specific contexts. One such 
notable program is the Australian Network for Japanese Law (ANJeL), a partnership between Chuo University the University of Melbourne [26]. Another is an engineering course co-designed and offered by the University of Virginia in the US and the TU Dortmund University in Germany [24].

\section{CUltural CONCERnS}

As of 2013, institutions in UK enrolled almost 400,000 transnational students in 217 foreign countries [30]. A single US-based institution, the University of Maryland University College, hosts over 200,000 foreign students in its online programs annually [33]. Given the multinational reach of many institutions in English-speaking nations, it is easy to understand why educational imperialism is a serious global concern. General agreement exists that transnational teaching needs to be culturally sensitive, yet there are differing opinions as to how this might be accomplished.

Widespread use of the English language in transnational higher education programs is a culturally complex matter. A few institutions work around the issue by teaching in multiple languages. Babeş-Bolyai University in Romania, for example, offers online business courses in four different languages: Romanian, Hungarian, German, and English [12]. This approach is interesting, but not always practical.

Adopting the English language for educational purposes has greatly assisted many nations in developing robust transnational partnerships. Malaysia, for example, adopted English for higher education in the 1980s. Over the past 35 years, Malaysia has entered into successful partnership programs with myriad universities in the US, UK, and Australia. Indonesia and Singapore have also shifted away from "mother-tongue medium of instruction" to English [19]. Many other Asian nations, notably China, use a bilingual approach. Colleges and universities in the People's Republic of China are now under government mandate to adopt English as the language for instruction in a variety of disciplines ranging from biotechnology to law [19].

It is widely recognized that constructivist approaches to teaching and learning dominate distance learning programs. A popular colloquialism refers to this phenomenon as the "sage on the stage" being replaced by the "guide on the side" [3]. Scholars are far from consensus as to whether teaching and learning in a non-native language serves as a barrier to making meaning in a constructivist environment.

In addition to the issue of language itself, one must consider the impact of cultural context on learning in transnational education programs. The English-speaking nations of Australia, UK, and US, which are also home to the predominant transnational education provider institutions, are low context and individualistic cultures. In these cultures, presentation of information is explicit, and almost all meaning is conveyed in actual, literal words. In stark contrast many of the Asian and Middle Eastern nations in which large numbers of transnational students live are high context and collectivist cultures. In high context cultures, presentation of information is often implicit, with meaning conveyed through gesticulation and other social cues as much as in actual words [13]. Learners from high context and low context cultures are particularly challenged when their efforts to reach understanding with one another take place in a virtual environment. The relative lack of body language and heavy reliance upon written words in online learning environments can pose a challenge to learners from high context cultures, many of whom are already challenged by learning in a non-native English language environment.

These are complicated issues. The reality is, globalization is a potent force, arguably surpassing even industrialization in scope and scale of impact. As explained by the authors in reference [33], "finding the golden triangle between widening access to higher education, high quality teaching, and providing economies-of-scale constitutes an immense challenge for the large-scale distance teaching opportunities." This brings us to yet another challenge.

\section{QUALITY CONCERNS}

Perceptions of quality in online and other distance education programs vary significantly throughout the world. In the United States, the overwhelming majority of academic leaders perceive the learning outcomes in online programs as "the same or superior to those in face-to-face" [4]. Quality control measures in the US are fairly robust. Benchmarks for quality assurance were rolled out by the former US-based Global Alliance for Transnational Education in 1995, and were realigned by the United States Distance Learning Association in 2003. An interesting case study of the educational policies of the 50 states comprising the US revealed comprehensive regulations governing expansion, competition, administration, and quality control of programs allowed to operate within individual states [15].

In sharp contrast, education leaders in Africa consistently express concerns about the low quality and questionable accreditation of foreign transnational education providers, particularly when those providers are for-profit institutions. Successful transnational education programs on the African continent do exist, such as the collaborative partnership between Intel College in Kenya and the University of Sunderland in the UK, but these high quality programs may be the exception rather than the rule. Overall, the gap between quality and cost is at times so apparent that transnational education as a means of building developing nations is viewed skeptically, even disparagingly [23]. This dichotomy in perception suggests a need for globally recognized standards, applicable in developing nations to the same extent as the rest of the world.

A wide variety of international agencies including UNESCO, the Asia-Pacific Quality Network, and the International Network for Quality Assurance Agencies in Higher Education have been gathering data related to the quality of transnational education programs for a decade or longer. With remarkable consistency, data shows that quality control measures correlate with the developmental stages of nations [23]. Along a wide continuum, transnational education providers are subject to increasing global scrutiny. Measures used by individual nations to govern foreign providers include evaluation of accreditation, restriction of student loan eligibility, copyright regulations, and residency restrictions [3].

India and Australia offer excellent examples of carefully 
planned transnational education programs, which may well serve as models for other nations. The National Assessment and Accreditation Council (NAAC) in India and the Australian Universities Quality Agency (AUQA) in Australia have been collaborating on quality assurance measures with mutual success since 2001 [23].

China faces unique transnational education quality concerns, in light of both more rapid enrollment expansion and more recent membership in the World Trade Organization than many other nations. Rapid expansion has led to predictable quality concerns related to effective administration of new programs and overall capacity building [8]. In addition, China is heavily vested in assuring quality in the context of what some stakeholders view as cultural appropriateness of transnational education [6]. The goals of transnational education students themselves seem to be unique in China, as well. Often, distance education programs administered by foreign institutions are viewed as a third choice, behind acceptance into a Chinese university and behind acceptance at traditional brick-and-mortar universities abroad. Many Chinese students enroll in transnational education programs as a transitional step, in hopes of earning acceptance into face-to-face programs at either a domestic or foreign university [9]. For these students, the quality of their transnational education program is of particular significance.

\section{CONCLUSIONS}

Transnational education programs offer great promise for expanding access to higher education for individuals throughout the world, with far fewer geographical and geopolitical barriers than traditional, face-to-face college and university programs. Properly designed and carefully implemented, transnational education programs hold the potential to greatly assist developing nations in expanding their intellectual infrastructure. These programs also hold the potential to increase the preparedness of students in many nations to work collaboratively within and beyond their increasingly globalized societies.

However, the potential benefits of transnational education programs must be weighed against the risks of educational imperialism. The importance of this concern cannot be overstated, given the prevalence of transnational education providers in English-speaking nations. The cultural capital of receiving nations, particularly developing nations, must be protected by well-planned and collaboratively administered quality control measures.

\section{REFERENCES}

[1] A. Aggarwal, "Higher education collaboration in Kenya: Challenges and perspectives," International Journal of Technology and Educational Marketing, vol. 3, issue 1, pp. 48-64, 2013.

[2] E. Pantò and A. Comas-Quinn, "The challenge of open education," Journal of e-Learning and Knowledge Society, vol. 9, no. 1, pp. 11-22, 2013.

[3] A. Simsek, "Global trends in distance education," presented at the International Conference on Communication, Media, Technology, and Design, Famagusta - North Cyprus, May 2-4, 2013.

[4] E. Allen and J. Seaman, "Changing course: Ten years of tracking online education in the United States," Tenth Annual Report of the Babson Survey Research Group, 2013.

[5] F. S. Barasa, "Quality assurance in distance higher education in Africa: Trends, issues, and challenges," presented at the UTPL, CREAD, and
VIRTUAL EDUCA Congress on Quality and New Tendencies in Distance Education: Knowledge Management and Web 2.0, Loja, Ecuador, October 20-22, 2010.

[6] R. Yang, "Transnational higher education in China: Contexts, characteristics, and concerns," Australian Journal of Education, vol. 52, no. 3, pp. 272-286, 2008.

[7] P. Altbach, "Chinese higher education in an open-door era," The International Imperative in Higher Education, Global Perspectives on Higher Education, pp. 157-161, 2013.

[8] X. Xu and Y. Kan, "Cross-border higher education in China in the globalized world: The perspective of the World Trade Organization's general agreement on trade in services," KEDI Journal of Educational Policy, vol. 10, issue 2, pp. 199-220, 2013

[9] W. Fang and S. Wang, "Chinese students' choice of transnational higher education in a globalized higher education market: A case study of W University," Journal of Studies in International Education, 2014.

[10] T. Saarinen, "Whose quality? Social actors in the interface of transnational and national higher education policy," Discourse: Studies in the Cultural Politics of Education, vol. 29, no. 2, pp. 179-193, 2008

[11] A. Zare, "Iran's entry into the globalmarket for higher education," Life Science Journal, vol. 10, no. 12sm pp. 167-172, 2013.

[12] M. Tutunea, R. V. Rus, and V. Toader, "Traditional education vs e-learning in the vision of Romanian business students," International Journal of Education and Information Technologies, vol. 3, issue 1, pp. 46-55, 2009.

[13] A. Hamdan, "The reciprocal and correlative relationship between learning culture and online education: A case from Saudi Arabia," The International Review of Research in Open and Distance Learning, vol. 15 , no. 1, p. 309, 2014

[14] S. Wilkins and M. Stephens Balakrishnan, "Assessing student satisfaction in transnational higher education," Educational Management, vol. 27, no. 2, pp. 143-156, 2013.

[15] J. E. Lane, K. Kinser, and D. Knox, "Regulating cross-border higher education: A case study of the United States," Higher Education Policy, vol. 26, pp. 147-172, 2013

[16] K. Jordan, "Initial trends in enrolment and completion of massive open online courses," The International Review of Research in Open and Distance Learning, vol. 5, no. 1, pp. 133-160, 2014

[17] V. Kumar, "Open-online education systems: A comparison of India \& China," Indian Journal of Applied \& Clinical Sociology, vol. 9, issue 1, pp. 126-128, 2014

[18] S. Deb, "Distance education through mobile technology can bring progress in developing countries," Journal of Communication and Computer, vol. 10, pp. 490-495, 2013.

[19] S. K. Gill and A. Kirkpatrick, "English in Asian and European higher education," in The Encyclopedia of Applied Linguistics, C. Chapelle, Ed., Blackwell Publishing Ltd., 2013.

[20] R. Bhandari and P. Blumenthal, International Students and Global Mobility in Higher Education: National Trends and New Directions, New York, NY: Palgrave Macmillian, 2011.

[21] S. Wilkins, M. S. Balakrishnan, and J. Huisman, "Student satisfaction and student perceptions of quality at international branch campuses in the United Arab Emirates," Journal of Higher Education Policy and Management, vol. 35, no. 5, pp. 543-556, 2012.

[22] M. Pilkington and G. Nair, "Global trends in higher education: An unexpected convergence between France and India," International Journal of Education Economics and Development, vol. 4, no. 1, pp. 1-19, 2013.

[23] A. Stella and D. Woodhouse, "Evolving dimensions of transnational education," Quality Assurance of Transnational Higher Education: The Experiences of Australia and India, Australia Universities Quality Agency and the National University of Educational Planning and Administration, 2011.

[24] D. May, "Engineering the future: A global endeavor," presented at the $1^{\text {st }}$ International Conference of the Portuguese Society for Engineering Education, October 31 - November 1, 2013.

[25] R. K. Sidhu and P. Christie, "Transnational higher education as a gybrid global/local space: A case study of a Malaysian-Australian joint venture," Journal of Sociology, 2014.

[26] M. Nichol, "Transnational legal education: A comparative study of Japan and Australia," Osaka University Law Review, no. 60, pp. 127-144, 2013.

[27] G. McBurnie and C. Ziguras, "The regulation of transnational higher education in Southeast Asia: Case studies of Hong Kong, Malaysia and Australia," Higher Education, vol. 42, no. 1, pp. 85-105, 2001.

[28] C. B. Lim and T. Evans, Australian Transnational Higher Education Quality Assurance in Singapore and Malaysia, Deacon University, 2011. 
[29] K. Smith, "Assuring quality in transnational higher education: A matter of collaboration or control?" Studies in Higher Education, vol. 35, no. 7, pp. 793-806, 2010.

[30] J. Waters and M. Leung, "A colourful university life? Transnational higher education and the spatial dimensions of institutional social capital in Hong Kong," Population, Space and Place, vol. 19, no. 2, pp. 155-167, 2013.

[31] D. Pyvis, "The need for context-sensitive measures of educational quality in transnational higher education," Teaching in Higher Education, vol. 16, no. 6, pp. 733-744, 2011.

[32] B. Tynan and R. James, "Distance education regulatory frameworks: Readiness for openness in Southwest Pacific/South East Asia region nations," Open Praxis, vol. 5, issue 1, pp. 91-97, 2013.

[33] S. Guri-Rosenblit, "Open/distance teaching universities worldwide: Current challenges and future prospects," EudAkcja Magazyn, vol. 2, no. 4, pp. 4-12, 2012.

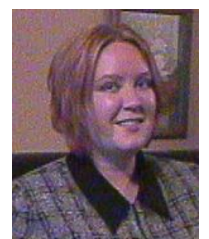

Betsy J. Bannier earned her Ph.D. in adult and continuing education with an emphasis in online chemistry education at University of Wisconsin Milwaukee (USA) in 2009. She earned her M.S. in analytical chemistry with a cognate in chemical education at University of North Dakota (Grand Forks, ND USA) in 2000, and her B.A. in mathematics and chemistry at Alverno College (Milwaukee, WI USA) in 1997.

She is an associate professor of chemistry and mathematics online at Lake Region State College in Devils Lake, North Dakota. She has 16 years of experience teaching in higher education, primarily in the field of undergraduate, online laboratory chemistry. In her current position, she serves as both an online master course developer and a mentor for new online faculty. She serves on several international review boards and her work has been published in a wide variety of journals. Her current research interests include the motivation of adult online students, learning strategies in online classrooms, and transnational online education. 